\section{A. ARS BILDUMA ISSN 1989-9262 UPV/EHU Press} ARSBILDUMA (CC BY-NC-ND 4.0)

https://doi.org/10.1387/ars-bilduma.20024 BIBLID [(2019), 9; 137-153]

Recibido: 27/06/2018 Aceptado: 25/07/2018

\section{EVA DÍEZ PATON}

Universidad del País Vasco (UPV/EHU)

Facultad de Letras

Paseo de la Universidad, 5

01006, Vitoria-Gasteiz (Álava)

eva.diez@ehu.eus

ORCID: 0000-0001-5299-9782

Miembro del Grupo de Investigación en Patrimonio Construido (GPAC).

\title{
LA JUNTA DE CULTURA VASCA Y LA REDACCIÓN DE UN CATÁLOGO MONUMENTAL PARA BIZKAIA (1917-1936)
}

THE BASQUE BOARD OF CULTURE AND THE REALIZATION OF A CATALOGUE OF THE MONUMENTS OF BISCAY (1917-1936)

\section{EUSKAL KULTURAREN KONTSEILUA ETA BIZKAIKO KATALOGO MONUMENTA- LAREN EGITEA (1917-1936)}

\section{RESUMEN}

Los catálogos monumentales deben considerarse instrumentos clave para la definición de las políticas de conservación patrimonial de las instituciones. La Junta de Cultura Vasca, dependiente de la Diputación de Bizkaia, estaba llamada a gestionar la política en torno a la conservación y restauración monumental. En el presente artículo se analizan los malogrados proyectos de la Junta de Cultura Vasca para la redacción de un catálogo monumental para Bizkaia.

PALABRAS CLAVE

Junta de Cultura Vasca; catálogo monumental; inventario; Bizkaia; patrimonio.
ABSTRACT

The catalogs of monuments should be considered as key instruments for the definition of the patrimonial conservation policies of the institutions. The Basque Board of Culture, dependent of the Diputación de Bizkaia, was called to manage the policy around the conservation and monumental restoration. In the present article the failed projects of the Basque Culture Board are analyzed for the writing of a catalogue of the monuments of Biscay.

\section{KEYWORDS}

Basque Board of Culture; catalogue of the monuments; inventory; Biscay; heritage.

\section{LABURPENA}

Monumentuen katalogoak funtsezko baliabideak dira erakundeen ondare-kontserbazio politiken definiziorako. Euskal Kulturaren Kontseilua, Bizkaiko diputazioaren menpekoa, monumentuen kontserbazio eta zaharberritzearen inguruko politika kudeatzera deituta zegoen. Artikulu honetan Euskal Kulturaren Kontseiluak Bizkaiko monumentuen katologoa egiteko huts egindako proiektuak aztertzen dira.

\section{GAKO-HITZAK}

Euskal Kulturaren Kontseilua; monumentuen katalogoa; inbentario; ondare. 


\section{CONOCER PARA CATAlOgAR; CATAlOGAR PARA CONSERVAR}

En la actualidad, es indudable la importancia de la continua elaboración de catálogos e inventarios para una adecuada conservación del patrimonio. La legislación nacional y autonómica en torno al patrimonio histórico y cultural, así como las cartas y convenios internacionales, defienden la redacción de catálogos e inventarios como instrumentos imprescindibles para una correcta tutela y protección. Y es que, como suele afirmarse al tratar sobre catalogación y patrimonio, "no podemos proteger lo que no conocemos"1.

Sin embargo, si la historia de la formación del catálogo monumental de España es la historia de un proyecto malogrado, el intento de creación del catálogo de monumentos de Bizkaia puede calificarse asimismo de fracaso. La proximidad y familiaridad del patrimonio, especialmente el arquitectónico, y su relevante papel hoy en la atracción y fomento del turismo, puede conllevar la percepción de un invariable conocimiento del mismo. Alfredo J. Morales, en una fecha no tan lejana como 1997, señalaba la falta de conocimiento de España hacia su patrimonio cultural ${ }^{2}$; Alfonso Muñoz Cosme, por su parte, afirmaba cómo el diverso patrimonio cultural español "ha sido escasamente conocido e insuficientemente protegido durante la mayor parte del siglo $\mathrm{XX}^{\text {"3. }}$.

Los términos catálogo e inventario se emplearon de manera indistinta en la primera mitad del siglo XX, siendo conveniente su definición. Catálogo proviene del latín catalogus y éste del griego katálogos, cuyo significado sería lista o registro. La Real Academia de la Lengua define catálogo como una relación ordenada de elementos que están relacionados entre sí. Inventario, a su vez, deriva del latín inventarium y éste del verbo invenire, significando, respectivamente, lista y encontrar. La Real Academia de la Lengua, además, define inventario como "Asiento de los bienes y demás cosas pertenecientes a una persona o

1 RISQUEZ CUENCA, C.: "Catalogación del patrimonio histórico. (Cuadernos. Instituto Andaluz del Patrimonio Histórico)", Arqueología y Territorio Medieval, vol. 4, 1997, p. 243

MORALES, Alfredo J: "El historiador del Arte ante la actual problemática del patrimonio cultural", citado por GARCÍA CUETOS, M.P.: El patrimonio cultural. Conceptos básicos. Zaragoza, Prensas Universitarias de Zaragoza, 2011, p. 111

3 MUÑOZ COSME, A.: "Catálogos e inventarios del Patrimonio en España", en Catálogo monumental de España (1900-1961), investigación, restauración y difusión. Madrid, Ministerio de Educación Cultura y Deporte, Secretaría General Técnica, 2012, p. 16. comunidad, hecho con orden y precisión"4. De esta manera, para la formación de ambos se requiere de un primer paso de reconocimiento e identificación del patrimonio.

Catálogos e inventarios son instrumentos de "conservación indirecta", es decir, medios para proteger de manera preventiva el patrimonio cultural ${ }^{5}$. El inventario, de connotación contable $^{6}$, debe entenderse como un "banco de datos que suministra las primeras fuentes para el estudio de la investigación científica"7. El catálogo, por el contrario, posee un carácter más extenso y requiere de un mayor trabajo de documentación e investigación; promueve la caracterización del objeto patrimonial, valorándolo y estudiándolo en múltiples aspectos, como los históricos, artísticos y de estado de conservación ${ }^{8}$. En definitiva, catálogos e inventarios son instrumentos que posibilitan la protección y salvaguarda del patrimonio, dado que a partir de ellos las instituciones y organismos pueden definir políticas de conservación patrimonial, identificando y reconociendo los elementos a preservar. No olvidemos, como señalan Francesca Tugores y Rosa Planas, que la no inclusión de un bien en un inventario o catálogo supone la inexistencia de éste a nivel administrativo y, por lo tanto, ser excluido de cualquier acción conservadora9 ${ }^{9}$. Ambos son instrumentos esenciales para el reconocimiento, protección y difusión del patrimonio de los países y comunidades.

\section{LEGISLACIÓN PARA LA FORMACIÓN DE UN CATÁLOGO MONU- MENTAL DE ESPAÑA}

La elaboración de catálogos e inventarios en España se revela una cuestión antigua y de largo recorrido; una "vieja obsesión" en palabras de María Ángeles Querol ${ }^{10}$. El siglo XIX puede ser considerado el momento del despertar hacia la necesidad de proteger, estudiar y difundir el patrimonio conservado. Sin embargo, las primeras medidas promovidas para

Real Academia Española. (2014). Diccionario de la lengua española (23. ${ }^{a}$ ed.). Consultado en http:/ www.rae.es/rae.html; GONZÁLEZ-VARAS, I.: Conservación de bienes culturales. Teoría, historia, principios y normas. Madrid, Cátedra, 2003, pp. 538 y 541.

5 GARCÍA CUETOS, M.P.: op. cit., p. 110; GONZÁLEZ-VARAS, I.: op. cit., pp. 538 y 541

6 BENAVIDES SOLÍS, J.: Diccionario razonado de bienes culturales. Sevilla, Editorial Padilla, 1999, p. 108. Artículo $4^{\circ}$ de la Carta Internacional para la gestión del patrimonio arqueológico, ICOMOS, 1990 disponible en: htps//Wwwicoms. PLANAS, R. Introducción al patrimonio cultural Gijón, Trea, 2006, pp. 81-82.

8 GONZÁLEZ-VARAS, I.: op. cit., pp. 539.

TUGORES, F. y PLANAS, R.: op. cit., p. 8

10 QUEROL, M.A.: Manual de gestión del patrimonio cultural. Madrid, Editorial Akal, 2010, p. 64. 
el inventariado y catalogación del patrimonio resultaron infructuosas; ni las comisiones científicas y artísticas, creadas por las Reales Órdenes de 29 de julio de 1835 y 27 de mayo de 1837, ni las Comisiones Provinciales de Monumentos, nacidas por Real Decreto de 13 de junio de $1844^{11}$, fueron capaces de recoger la riqueza patrimonial del país.

Esta situación pretendía invertirse por medio del Real Decreto de 1 de junio de 1900 que disponía la "formación del Catálogo monumental y artístico de la Nación"12. La obra se dividiría en provincias, dedicando un tomo o cuaderno que describiera las riquezas monumentales y artísticas de cada una de ellas, "no pasando de una a otra sin que esté completamente terminado el Catálogo histórico y artístico de aquella en que se haya comenzado la investigación". La Real Academia de Bellas Artes de San Fernando encomendó la totalidad del proyecto a Manuel Gómez-Moreno, comenzando la redacción por la provincia de Ávila ${ }^{13}$. Este decreto fue duramente criticado por personalidades de la época, como demuestran las palabras del arquitecto Jeroni Martorell: "iQué desconocimiento de la realidad indicaba esta resolución! España es muy grande; el caudal de arte que en ella existe, inmenso, fabuloso; mucho mayor que lo supuesto por la Academia"14. Rafael Balsa de la Vega, en esta misma línea, consideraba un error encomendar la redacción a una única persona, apostillando, en tono burlón, que se necesitarían 31 años para su conclusión ${ }^{15}$.

La Academia, consciente de la necesidad de modificaciones, anunció un nuevo método para alcanzar la redacción del catálogo monumental. Por Real Decreto de 14 de febrero de $1902^{16}$ se dividió el territorio en tres secciones (Castilla y León, Andalucía y Extremadura y las Coronas de Aragón y de Navarra), a cargo cada una de ellas de una o varias personas nombradas por el ministro de Instrucción Pública y Bellas Artes. Los inventarios debían contar con una descripción y estudio crítico del patrimonio, historia de los monumentos

1 Sobre este tema ver ORDIERES DIEZ, I.: Historia de la restauración monumental en España (1835 1936). Madrid, Instituto de Conservación y Restauración de Bienes Culturales, 1995.

12 Gaceta de Madrid, año CCXXXIX, n. ${ }^{\circ} 153,2$ de junio de 1900.

13 Ibid., p. 1.081

14 MARTORELL, J.: "El patrimonio artístico nacional", Arquitectura, año II, 1919, p. 155.

15 BALSA DE LA VEGA, R.: "El catálogo monumental y artístico de la nación", La Ilustración Española Americana, año XLIV, n. ${ }^{\circ}$ XXIII, 22 de julio de 1900, p. 367, citado por LÓPEZ-YARTO ELIZALDE, A. El catálogo monumental de España (1900-1961). Madrid, Consejo Superior de Investigaciones Científicas, 2010, p. 14 .

16 Gaceta de Madrid, año CCXLI, n. ${ }^{\circ} 49,18$ de febrero de 1902, p. 733 y acompañarse de dibujos, planos y fotografías ${ }^{17}$. Esta vez Martorell consideró que el resultado serían meros libros de historia dedicados a la especialidad predilecta de cada autor $^{18}$; Leopoldo Torres Balbás, por su parte, definió los trabajos como "obra de periodistas y amigos de políticos desconocedores en absoluto de nuestro arte antiguo"19.

La subsecretaría del Ministerio de Instrucción Pública y Bellas Artes se puso en contacto en 1913 con la Comisión de Monumentos de Vizcaya (CMV) para comunicarle el nombramiento de Cristóbal de Castro para catalogar los monumentos artísticos de la provincia. Sin embargo, el rechazo al nombramiento fue inmediato. Julián de San Pelayo, en calidad de presidente, excusó "la necesidad del nombramiento de ordenador del catálogo de Monumentos provinciales" por considerarlo lesivo para los intereses del erario público y del prestigio de la CMV, "asumiendo la Junta esta delicada función" ${ }^{20}$. De esta manera, y aunque la Real Orden de 14 de febrero de 1902 especificaba que la redacción del catálogo se comisionaría a un individuo cuyo trabajo sería remunerado, en el caso de Bizkaia se prescindió conscientemente de la legislación y se aplaudió el "generoso ofrecimiento" de una comisión de "reconocida competencia [...] que habrá de realizar con todo acierto la obra de referencia"21. El catálogo monumental de Bizkaia ni se publicó ni se inició siquiera.

Por Real Decreto de 14 de febrero de 1922 se actualizó la realización del catálogo monumental encargándose su publicación a la Real Academia de Bellas Artes de San Fernando y a la Real Academia de la Historia, para lo que se nombró una comisión especial formada por tres individuos, uno de la Real Academia Española de la Lengua y los otros dos de las anteriormente citadas ${ }^{22}$. A esta ley siguieron varias promulgaciones, destacando el Real Decreto de 9 de agosto de 1926, que supusieron un nuevo intento de confeccionar

17 La comisión tendría una dotación mensual de 800 pesetas. Se realizaron las obras de las provincias de León, Ávila, Jaén, Cádiz y Teruel, entre otras, pero la única que se llegó a publicar fue la de Álava, obr de Cristóbal de Castro Gutiérrez.

8 MARTORELL, J.: op. cit., p. 155.

19 TORRES BALBÁS, L., "Los monumentos históricos y artísticos. La desorganización y sus servicios", p. 2, citado por GANAU CASAS, J.: La protección de los monumentos arquitectónicos en España y Cataluña, 1844-1936: legislación, organización, inventario. Lleida, Universidad de Lleida, 1999, p. 43.

20 Boletín de la Comisión de Monumentos de Vizcaya, tomo V, año V, 1913, p. 8.

21 El 2 de enero de 1914 se acordó que el catálogo monumental de la provincia de Bizkaia, mandado formar por Real Orden de 20 de octubre de 1913, se encargara a la Comisión de Monumentos de Vizcaya. Ver: "Reales órdenes", Boletín de a Comisión de Monumentos de Vizcaya, t. VI, primer trimestre de 1914, p. 14.

22 Gaceta de Madrid, año CCLXI, n. ${ }^{\circ}$ 56, 25 de febrero de 1922, p. 854. 
una herramienta para la "defensa de la riqueza monumental y artística" del país, y que instaban a ayuntamientos, diputaciones provinciales, etc., a confeccionar listas con los monumentos de cada región. A pesar de todo, fueron escasas las provincias de las que se realizó una monografía y prácticamente ninguna fue publicada, por lo que carecieron de eficacia como medio de ayuda a la conservación monumental ${ }^{23}$.

El Real Decreto de 15 de mayo de $1930^{24}$ buscaba la realización del "Inventario General de los Monumentos históricos y artísticos del Reino" desde la consciencia de lo inapropiado y de la necesidad de revisión de algunos de los catálogos redactados. Con el deseo de dar un mayor rigor científico al proyecto, se acordó encomendar al Laboratorio o Instituto de Historia del Arte y Arqueología de la Universidad de Madrid la revisión y redacción del catálogo monumental, dado que ciertas provincias aún no lo habían elaborado.

El Fichero de Arte Antiguo, encomendado a las Secciones de Arte y Arqueología del Centro de Estudios Históricos por Real Decreto de 13 de julio de $1931^{25}$, estaba llamado a ser el inventario de las obras de arte de la nación "anteriores a 1850". La Delegación General de Bellas Artes buscaba una herramienta que aportara informaciones técnicas "precisas y rápidas" sobre el estado de un monumento o la importancia de un objeto artístico, que "no pueden llenar las Academias ni los demás cuerpo Consultivos, porque en su actuación es obligada mayor lentitud de la requerida en muchos casos de notoria urgencia". Para ello se utilizaría la documentación custodiada en las Secciones de Arte y Arqueología del Centro de Estudio Históricos, formadas por varios millares de fotografías, y los catálogos monumentales redactados hasta el momento. Se formaría además un fichero especial de las obras de arte destruidas o exportadas desde $1875^{26}$

3 ORDIERES DIEZ, I.: op. cit., p. 62

24 Gaceta de Madrid, año CCLXIX, n. ${ }^{\circ} 136,16$ de mayo de 1930 p. 1067.

25 Gaceta de Madrid, año CCLXX, n. ${ }^{\circ} 195,14$ de julio de 1931, p. 382.

26 Las Secciones de Arte y Arqueología del Centro de Estudios Históricos también debían formar un "Fichero especial" con las obras de arte destruidas o exportadas desde 1875 hasta la fecha. "Artículo 4. [ ] Cada ficha constaŕ de la fotografía del monumento u objeto y de cuntos dato dedor intermedias precio o precios sucesivos acara enajenación, etc., además del resumen histórico y de la clasificación. Este Fichero se publicará por artes, regiones, a expensas del Ministerio de Instrucción pública y Bellas Artes y la publicación estará a cargo de las Secciones de Arte y Arqueología del Centro de Estudios Históricos."
La Ley del Patrimonio Artístico Nacional del 13 de mayo de 1933 insistía en la redacción del Inventario del Patrimonio Histórico-Artístico ${ }^{27}$, tomando como base los catálogos monumentales y el Fichero de Arte Antiguo. Las corporaciones y entidades, tanto civiles como eclesiásticas, debían remitir en el plazo de seis meses una relación de los bienes inmuebles y objetos muebles en su posesión al delegado provincial. Las relaciones debían ilustrarse con fotografías, dibujos, etc. y acompañarse de un catálogo, guía o estudio lo más minucioso y completo posible. Todo este material sería remitido por el delegado provincial a las juntas locales del Tesoro Artístico o a la Junta Superior; el Fichero de Arte Antiguo, por su parte, debía enviar cuantos informes y elementos poseyera en todo aquello que incumbiera a la elaboración del inventario y catálogo ${ }^{28}$.

Cabe destacar, finalmente, la publicación por parte del Fichero de Arte Antiguo de Monumentos españoles. Catálogo de los declarados nacionales, arquitectónico e históricoartísticos (1932), en cuya redacción y recogida de ilustraciones colaboraron Elías Tormo, Manuel Gómez-Moreno, Leopoldo Torres Balbás o Francisco Javier Sánchez Cantón, entre otros. Este índice incompleto de la riqueza monumental de España, agrupado por provincias y dividido en dos tomos, recogía algunos ejemplos vizcaínos: la basílica del Señor Santiago de Bilbao, la cueva de Santimamiñe en Kortezubi, la necrópolis de Argüiñeta, la iglesia de Santa María de Galdakao y la basílica de Nuestra Señora de la Asunción de Lekeitio ${ }^{29}$.

\section{LA JUNTA DE CULTURA VASCA}

El 4 de octubre de 1917 se formó por acuerdo de la Diputación de Vizcaya la Junta de Cultura Vasca (JCV), cuyo objetivo era promover y estimular las ciencias, artes, lengua y costumbres del país. Entre la diversas secciones en que se dividió para una mejor organización, se creó, por acuerdo de 17 de enero de 1921, la sección de conservación de monumentos, que tenía entre sus funciones la creación de un catálogo de la riqueza artística de Bizkaia ${ }^{30}$

27 Gaceta de Madrid, año CCLXXII, n. ${ }^{\circ} 145,25$ de mayo de 1933, p. 1398. Título 5º arts. 66-72.

28 "Artículo 71. La Junta Superior del Tesoro Artístico atenderá, con sus recursos y con su vigilancia, a la confección, revisión y publicación de los Catálogos monumentales, utilizando la parte aprovechable de los entregados que permanecen inéditos".

29 Monumentos españoles. Catálogo de los declarados nacionales, arquitectónico e histórico-artísticos. Madrid, Blass, 1932, t. II, pp. 408-410

30 Un análisis exhaustivo sobre la formación de la Junta de Cultura Vasca y su vínculo con la conserva- 
La primera referencia a la formación de un inventario es una moción de los nacionalistas José Ignacio de Arana y el arquitecto Antonio de Araluce para la catalogación de las ermitas vizcaínas ${ }^{31}$. Denunciaban su estado de abandono frente a la atención que se prestaba a la conservación de edificaciones de carácter monumental, proponiendo que el inventario contribuyese a emprender pequeñas intervenciones para su conservación, "pues actualmente hasta aquellas elementales medidas de limpieza que por razones de higiene necesitan las ermitas se administran en muchos casos con el más deplorable de los gustos". Las ermitas particularizaban el paisaje vizcaíno y su existencia y valor, entendían, no era tan frecuente fuera de Bizkaia: "no han logrado el prestigio que aquí donde la ermita va siempre unida a algún suceso de carácter histórico y donde aparte de su significación religiosa, tiene su leyenda y especial veneración o lo que no es ajeno el espíritu localista de nuestro pueblo".

Por último, subrayaban su significación en la evocación de recuerdos y sucesos de "nuestra historia", su vínculo con costumbres y ritos de interés para los estudios etnográficos, y su valor estético, que podía contribuir a fomentar actividades económicas poco explotadas, como el turismo. La iniciativa, además, no requería de grandes sumas de dinero pues sólo pretendían una "conservación decorosa", es decir, dotarlas de las elementales medidas de higiene, pudiendo las partidas consignadas para la redacción del catálogo arqueológico y la conservación de monumentos asumir los gastos ocasionados ${ }^{32}$.

La fórmula elegida para dar inicio a la idea fue el envío a los curas párrocos de papeletas/ interrogatorios formadas por 11 puntos sobre asuntos constructivos, artísticos, documentales, prácticos y religiosos relativos a las ermitas a su cargo: número de ermitas establecidas bajo su jurisdicción, época de construcción, valor artístico, noticia sobre si contiene algún archivo o documento, designación de sus titulares, días en que se honra a los santos a los que están dedicadas, gracias especiales que se les atribuyen, nombre de los lugares en que se hallan situadas, distancia a la carretera, estado de conservación y obras necesarias ${ }^{33}$. Las preguntas sobre época de construcción, importancia artística y existencia

ción del patrimonio puede consultarse en: DÍEZ PATON, E.: Alma y piedra. Ideologías, conservación restauración. Política del patrimonio arquitectónico en Vizcaya (1844-1936). Universidad del País Vasco 2017, tesis doctoral inédita.

31 AHFB. Educación, Deportes y Turismo 72, Caja 993, Exp. 14. Moción fechada el 15 de enero de 1921.

$32 \mathrm{Ibid}$. El 28 de enero de 1921 se elevó a acuerdo la moción de Antonio de Araluce y José Ignacio de Arana.

33 Ibid. El cuestionario fue elevado a la aprobación de la JCV por Crescencio de Gardezabal el 1 de febrero de 1921 de archivo o documentos fueron añadidas a petición de Manuel María Smith y Fernando de la Quadra Salcedo; imaginamos que las dos primeras a propuesta del arquitecto y las referencias documentales a petición del escritor ${ }^{34}$.

La JCV vio en las sociedades deportivas y de excursiones una importante posibilidad de colaboración para la elaboración de relaciones y recogida de datos, logrando que la comisión alpina del Club Deportivo se sumase al proyecto y les facilitase noticias de las ermitas que fueran localizando en sus excursiones, detallando su "advocación, estado, jurisdicción, descripción, altitud, dimensiones, romería, particularidades, historia, etc. y fotografías, dibujos de su exterior y superficie en planta de su disposición"35. El envío de cuestionarios a los curas párrocos se inició el 16 de febrero de 1921, incluyendo 30 interrogatorios al Club Deportivo Alpinista, dando por terminada su recepción en junio. El resultado fueron 116 respuestas con referencia a 388 ermitas $^{36}$.

Las comarcas que más cuestionarios remitieron fueron Busturialdea, Duranguesado y Gran Bilbao, con referencias a más de 40 ermitas cada una; Arratia-Nervión, por su parte, aportó el menor número, sólo 26 ermitas. Analizando los puntos que pueden resultar más interesantes para nuestro estudio, "Época de construcción", "Su valor artístico", "Su actual estado de conservación" u "Obras que necesitan", la conclusión que obtenemos es la lógica incapacidad de los párrocos para responder a estas cuestiones. En sus escritos surgen impresiones y expresiones que suelen acompañar a quien carece de conocimientos históricos o artísticos. A la pregunta sobre la fecha de construcción la mayoría de las respuestas fueron que la desconocían, pero también fueron numerosas las alusiones a sus orígenes antiquísimos y remotos, a que se creía anterior a la iglesia, a que la tradición aseguraba que era la primitiva iglesia del municipio e incluso a que ni los ancianos lo sabían. Sorprenden, asimismo, las referencias a la obra del historiador Juan Ramón Iturriza o a la crónica histórica de Ibargüen-Cachopín, y las alusiones a la existencia de sepulturas para avalar la antigüedad de las ermitas. La aportación de una fecha exacta sólo fue habitual en las ermitas construidas entre los siglos XIX-XX, siendo excepcionales los casos de las

34 Ibid. Aprobado el 11 de febrero de 1921

35 Se pusieron como fecha límite de recopilación de datos el 30 de junio de 1921. Ver: "La moción sobre las ermitas", La Gaceta del Norte, año XXI, n. ${ }^{\circ} 7.281,12$ de febrero de 1921, p. 4.

36 AHFB. Educación, Deportes y Turismo 72, Caja 993, Exp. 14. Informe de Crescencio de Gardezabal fechado el 3 de junio de 1921. 


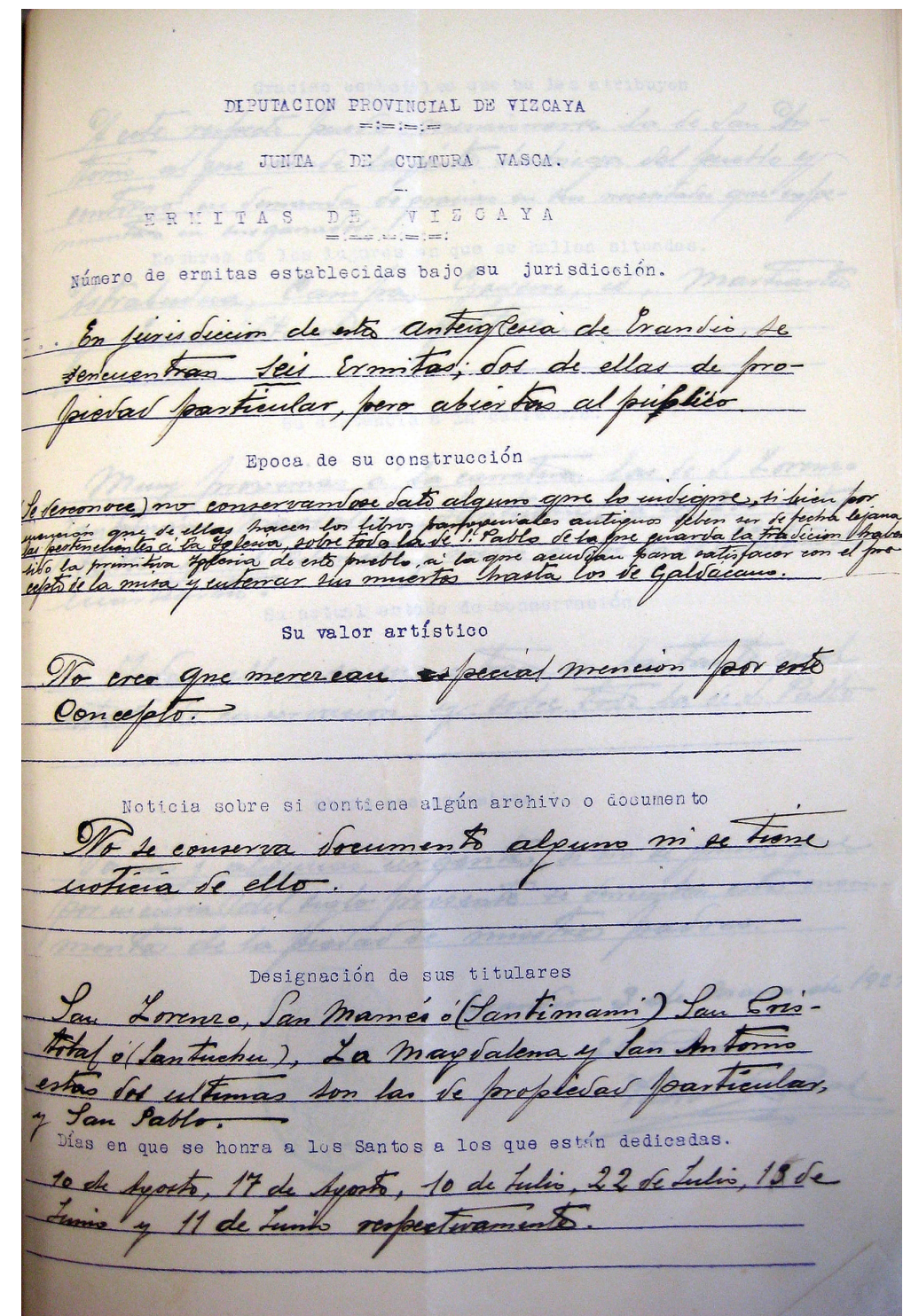

Fig. 1: Cuestionario completado por el párroco de Erandio para el inventario de las ermitas de Vizcaya (1921), AHFB. Educación, Deportes y Turismo 72, Caja 993, Exp. 14. ermitas de Nuestra Señora de las Nieves de Gorozika datada en 1496, San Roque en Orozko fechada en 1610, o Santa Marina en Urduliz situada en 1632 basándose en un documento conservado.

La información aportada sobre el valor artístico de las ermitas fue muy similar. Los párrocos, en su mayoría, consideraban que las construcciones carecían de interés, aunque en muchas ocasiones el valor artístico fue confundido con la conservación de objetos artísticos, como cuadros, retablos o imágenes. Las referencias ambiguas fueron también habituales, señalando un valor escaso, muy escaso e incluso pequeño; otras veces se aludía a una construcción sólida o bien hecha para dar respuesta a la pregunta, e incluso se zanjaba la cuestión con un rotundo "no entiendo". A falta de valor artístico, los párrocos resaltaban el valor de antigüedad, histórico y moral. Bernardino Garaizar, por ejemplo, afirmaba sobre las siete ermitas conservadas en el municipio de Bermeo: "No creo que ninguna encierre ninguna cosa notable, excepción hecha de la remotísima antigüedad de todas ellas"; frente a la construcción sencilla y vulgar de líneas irregulares de la ermita de la Inmaculada Concepción o de la Tala de Ea, sobresalía la devoción que se la tenía; y aunque las ermitas de San Antolín y San Salvador de Abadiño careciesen de valor artístico, destacaban por su valor histórico, pues en la casa situada junto a la primera se reunieron los generales Espartero y Maroto para poner fin a la Primera Guerra Carlista, mientras que en el recinto de la segunda se celebraban las juntas de la merindad de Durango.

Ante este estado de las cosas sorprende encontrar alguna alusión a elementos arquitectónicos, pero las hubo: las formas ojivales en las ermitas de Nabarniz, una ventana antigua añadida a la ermita de San Sebastián de Orozko que se creía de una antigua construcción, la "fachada interesante" de la ermita de la Piedad de Lekeitio, que a juicio del párroco podía poseer algún mérito, o la nota del párroco de las ermitas de Ibarruri, en el municipio de Muxika: "una de ellas merece la atención de los forasteros por su portada a mi juicio románica", única alusión al estilo en todos los cuestionarios, que deben tomarse con todas las cautelas posibles ${ }^{37}$. Las referencias a elementos escultóricos y estatuaria también están presentes, como la imagen de la Magdalena situada sobre la puerta de la ermita de Santa María Magdalena de Lekeitio o las de las ermitas de Aulesti, que evocaban la antigüedad de las construcciones: "Acaso las ventanas de piedra con un crucifijo en el

37 En este caso, la ermita de San Pedro de Ibarra, en el barrio de Ibarruri, se corresponde a una fábrica gótica, fechada hacia finales del siglo XV. Ver: BARRIO LOZA, J.A. (dir.): Bizkaia. Arqueología, urbanismo y arquitectura histórica, Bilbao: Universidad de Deusto-Deiker, 1990, t. II, p. 444 
centro actualmente tabicadas de los frontis de San Juan Bautista de Murélaga y San Lorenzo de Zubero. Algunas imágenes diminutas de cabeza desproporcionada. [...] Dos imágenes de piedra en San Juan Bautista y Santa Eufemia".

El estado de conservación de las ermitas se respondió con impresiones como bueno, malo o regular, siendo esta última la más frecuente. Las excepciones en las respuestas fueron de extremo a extremo, de un muy buen estado de conservación de las ermitas erigidas entre los siglos XIX-XX, a construcciones ruinosas o en situación "deplorable", "lamentabilísimo", "muy detestable" o de urgente necesidad de mejoras ${ }^{38}$. A pesar de estos datos, sólo 136 párrocos completaron el apartado sobre las obras necesarias, refiriéndose en su mayoría a intervenciones imprescindibles para asegurar el uso de las ermitas, como renovaciones o reformas completas interiores y exteriores: revoque y blanqueo de las paredes, arreglo del pavimento o entarimado, solucionar problemas de humedad, refuerzo de pórticos y retejos. La inversión de estas obras se justificó en algunos ejemplos por la antigüedad de la construcción (San Juan de Aulestia), por su valor histórico (Nuestra Señora en Izaro, Bermeo) o por las tradiciones, invitando en el caso de San Juan de Gaztelugatxe a que la Diputación se hiciese cargo de ella: "siguiendo las antiguas tradiciones declarándola monumento Señorial, [...] no hay en Vizcaya ermita tan visitada, dádose el caso singular de que esa devoción es tan entusiasta en nuestros bravos marinos como en nuestros baserritarras".

El destino y utilidad que la JCV quería dar a los datos obtenidos de los cuestionarios nunca fue tratado. Lo cierto es que esperar obtener una información práctica y fidedigna confiando en los conocimientos y buena voluntad de los párrocos era un tanto ilusorio. ¿Qué conocimientos podían tener sobre cuestiones artísticas? ¿cómo iban a determinar el valor de las ermitas? ¿en qué se basarían para datar las construcciones? Los cuestionarios podían ser una aproximación, un sondeo, pero no una base para saber el número de ermitas, valor artístico o estado de conservación, en todo caso podían servir para conocer cómo interpretaba la sociedad este tipo de cuestiones. Si se quería obtener un trabajo serio había que emprender un trabajo de campo, nombrando una comisión o personal

38 Se citan nueve ermitas en estado de ruina; 78 cuyo estado de conservación era regular; tres en situación muy detestable, lamentabilísimo y deplorable, junto a otras dos con grandísima necesidad de mejora cuatro en muy buena situación; 15 en estado de conservación mediano; 50 en mal estado; cinco deterioradas; una demolida; y 65 en buen estado de conservación; el resto no completaron este apartado. especializado para visitar, conocer y evaluar la situación de las ermitas, e ir formando el ansiado catálogo arquitectónico.

Una vez finalizada la recepción de cuestionarios se planteó señalar qué ermitas destacaban por su significación histórica o artística y estudiar las obras que requerían; mientras que aquellas que carecieran "de un mérito especial" no tendrían una atención preferente por parte de la JCV. Sin embargo, ordenar los cuestionarios y obtener conclusiones a partir de ellos parecía una idea poco práctica. La única medida que se tomó fue el anuncio de un concurso fotográfico ${ }^{39}$ como complemento a los interrogatorios, dejando en manos de los vocales Manuel María de Smith y Eugenio Leal el modo de llevarlo a cabo ${ }^{40}$, al que se presentaron Manuel Torcida Torre y otros particulares ${ }^{41}$. Debemos señalar que la única consecuencia directa que tuvo la iniciativa fue incitar a algunos feligreses a contribuir con donativos al arreglo de ermitas, como por ejemplo en San Pelayo y San Pedro de Miravalles; un ofrecimiento que Carmelo de Echegaray propuso aceptar siempre y cuando las obras no desnaturalizasen el edificio. Nunca más volvió a tratarse el tema ${ }^{42}$.

En conclusión, puede afirmarse que la utilidad del cuestionario fue prácticamente nula La JCV no se planteó ni visitar las construcciones, ni verificar los datos obtenidos, ni completarlos, sin olvidar que la información obtenida carecía del rigor necesario. Bizkaia tuvo que esperar para ver inventariadas sus ermitas a la publicación de Gurutzi Arregi Ermitas de Bizkaia (1987), donde la autora manifestaba las dificultades de tan compleja tarea: manejar la documentación e información de más de 500 ermitas, establecer un metodología, organización del trabajo, consulta de datos bibliográficos y documentales,

39 AHFB Educación, Deportes y Turismo 72, Caja 993, Exp. 14 Las bases del concurso eran las siguientes: $1^{\circ}$. Se admiten fotografías en diversas dimensiones y ejecutadas por profesionales y aficionados; $2^{\circ}$ Convendrá que de cada ermita se obtengan las que sean necesarias para dar idea exacta de ellas, con fotografías de detalle si el caso lo requiera; $3^{\circ}$. Se concederán varios premios en objetos de arte, y las fotografías que los merezcan por la importancia artística e histórica del pequeño monumento, en novedad y la dificultad material de obtenerlas; $4^{\circ}$. El fallo se hará por la comisión designada por la JCV de la Excma. Diputación, no teniendo derecho el concursante en ningún caso a la reclamación de sus fotografías.

40 Ibid. Acuerdo del 6 de julio de 1921.

41 Ibid. El concurso de fotografía se anunció el 3 de octubre de 1921.

42 Victoria de Ucelay propuso contribuir con 500 pesetas al arreglo del cielo raso de la ermita de San Pelayo y San Pedro de Miravalles, tras la apreciación de Echegaray la JCV decidió encargar el estudio y supervisión de la obra al arquitecto Manuel María de Smith. Aunque no volveremos a tener noticias sobre la intervención. Ver: AHFB. Educación, Deportes y Turismo 72, Caja 993, Exp. 14. Dado cuenta en las sesiones de 18 y 19 de julio de 1921 


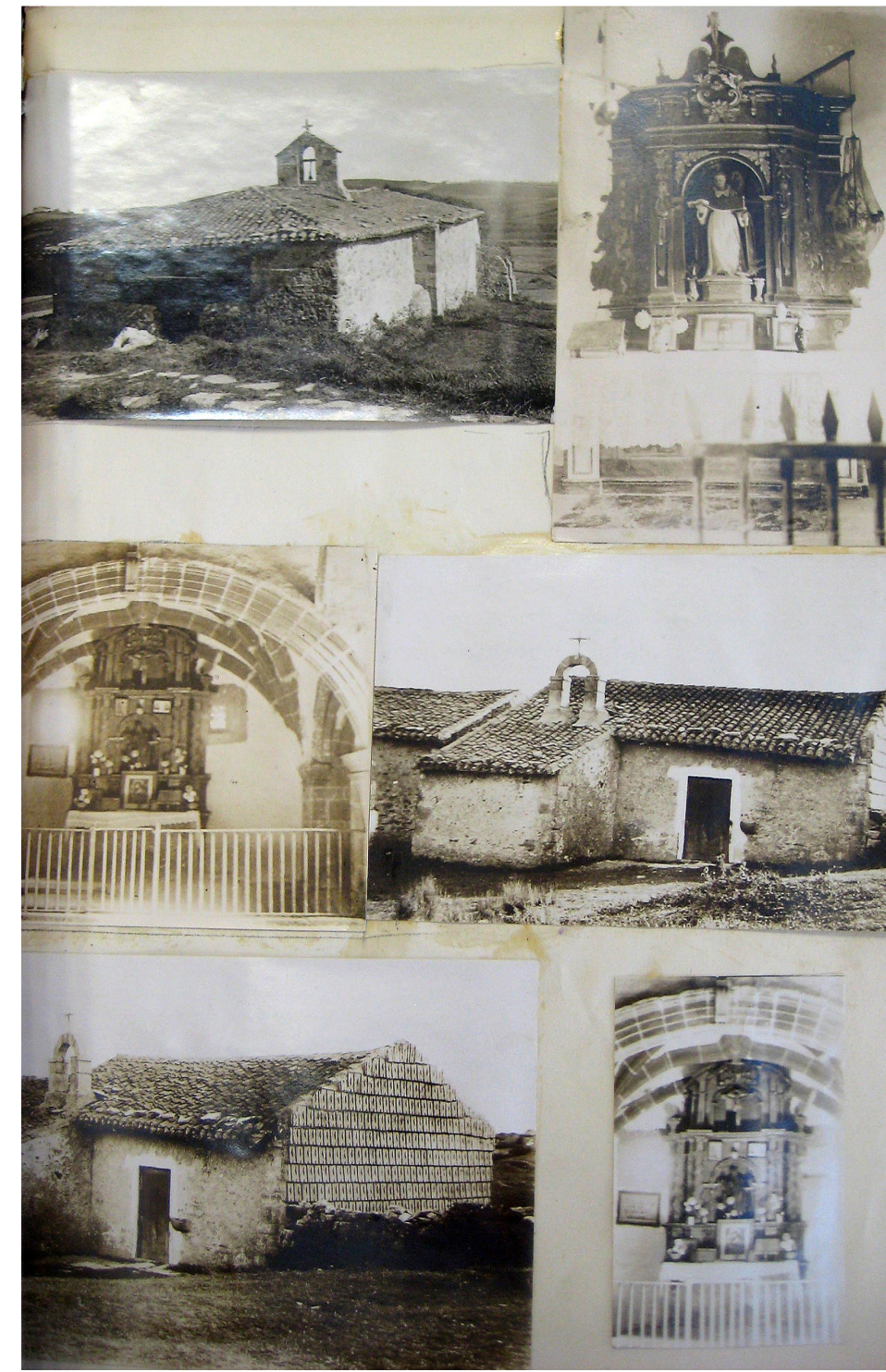

Fig. 2: Fotografías presentadas al concurso de ermitas de Vizcaya organizado por la JCV (1921), AHFB, Educación, Deportes y Turismo 72, Caja 993, Exp. 14. investigación de campo, análisis de epígrafes y descripciones, problemas tipológicos (humilladeros, santutxus, ermitas juraderas, ermitas de juntas, vinculadas con casastorre, aisladas, etc.), el doble carácter arquitectónico y etnográfico de las ermitas, entre otros muchos asuntos que dan prueba de las dificultades que entrañaba el estudio ${ }^{43}$. Esperar y confiar, desde una sala de reuniones del palacio foral, en la buena voluntad, rigor y conocimientos histórico-artísticos de los curas párrocos de Bizkaia para formar el inventario de las ermitas del territorio en base a un interrogatorio de 11 puntos era un delirio.

Fernando de la Quadra Salcedo presentó aquel mismo año una moción para inventariar los escudos de armas de Bizkaia. La propuesta era claramente un trasunto de los intereses del autor: la historia y la heráldica, cuestiones sobre las que llegó a dirigir en 1926 el Boletín del Instituto Heráldico. Ciencias histórico genealógicas, iconografía ${ }^{44}$. Para el escritor los escudos, adornando y dando prestigio a "antiguas torres, casas de solariego, y Palacio de armería" ahora convertidos en caseríos, se hallaban abandonados, caídos, destruidos o enajenados. Quadra Salcedo proponía rescatar su memoria y valor, pues su conservación y estudio contribuiría a conocer mejor el pasado y la arquitectura de la provincia, que "encuentra en los cuarteles de nuestros linajes y en sus paveses ornamentados la oculta y verdadera historia de los pasos que anduvo nuestra vida artística en los matices decorativos". El inventariado de los escudos de armas de Bizkaia debía hacerse "a la manera" de Nobiliario de el valle de la Valdorba (1714) de Francisco de Elorza y Rada; y ser llevado a la práctica designando a dos individuos: uno para que visitara y reconociera los escudos y el otro para dar fe de ellos, "escribano o notario para que se conserve su descripción y puedan surtir efectos dentro de los códigos civil y canónico". Una vez concluida esta tarea se iniciaría, según el caso, su conservación, restauración o enajenación, junto a la redacción de un "Libro de la materia"45.

La propuesta de Quadra Salcedo apostaba por el trabajo de campo, en este caso dos personas cuyos conocimientos nunca llegó a especificar. La JCV, sin embargo, optó de nuevo por la cómoda y económica opción de los cuestionarios, que serían redactados

43 ARREgI AZPeITIA, G.: Ermitas de Bizkaia. Bilbao, Diputación Foral de Bizkaia, Instituto Labayru, 1987 , t. I, pp. XVII-XXXIII.

44 Boletín del Instituto Heráldico. Ciencias histórico genealógicas, iconografía. Bilbao, Imprenta Erria, 1926. 45 AHFB. Fondo Administrativo. Sección Educación, Deportes y Turismo 77, Caja 998, Exp. 30. Escrito firmado el 29 de marzo de 1921 
por el mismo Quadra Salcedo y remitidos a todos los alcaldes de la provincia. En sus 13 puntos se solicitaba, entre otros asuntos, el número de escudos de armas, nombre y propietario de la casa, dimensiones y situación en el edificio, figuras y elementos que lo componían, material, inscripciones, decoración pictórica, época de construcción o estado de conservación del edificio ${ }^{46}$

El resultado e implicación de los 59 municipios que respondieron (de los 120 posibles) fue en muchos casos sorprendente, pues no sólo remitieron la documentación completada, sino que la enriquecieron con fotografías, croquis y dibujos de mayor o menor destreza. A pesar de ello, el contenido, especialmente en el aspecto histórico y arquitectónico, fue de nuevo limitado. Las referencias vuelven a basarse en impresiones, bien sobre la antigüedad, bien sobre el estado de conservación de los edificios: alusiones como bueno, malo o deteriorado, eran las más habituales, sumándose las igualmente personales referencias a la antigüedad de las fábricas: "por su aspecto tiene unos 200 años", "se ignora pero es antiquísima" o de los siglos XVII o XVIII, entre otras muchas.

Los cuestionarios sobre escudos de Bizkaia, a diferencia de la iniciativa para inventariar las ermitas, dieron como resultado la publicación de Escudos de Carranza (1928) de Manue López Gil, colaborador del Anuario de la Sociedad de Eusko-Folklore ${ }^{47}$. La propuesta de Fernando de la Quadra Salcedo, y su interés por la conservación de escudos de armas de Bizkaia, se adelantó a la legislación de la época: España promovió medidas legislativas para la protección de "escudos, piezas heráldicas, rollos de justicia, cruces de término y piezas análogas" por Real Decreto de 14 de marzo de $1963^{48}$. Bizkaia, de nuevo, tuvo que esperar algunos años más para ver completado este trabajo, cuando Javier Ybarra inició la publicación de su obra Escudos de Vizcaya (1967-1968), que recogía más de 1.000 referencias ${ }^{49}$

46 Cuestionario firmado por Fernando de la Quadra Salcedo y fechado el 7 de mayo de 1921. Aprobado por la JCV el 14 de mayo de 1921.

47 La obra quiso publicarse en un primer momento en el Boletín de la Comisión de Monumentos de Vizcaya a modo de tirada aparte de 50 folletos. Las gestiones duraron algo más de cinco años, pues la JCV trató que el mismo López Gil aportase fotografías y dibujos de los escudos analizados. El cura ecónomo, po su parte, rechazó la idea, así como Diego de Basterra arquitecto provincial y responsable de la oficina de aruitectura de la Diputación llegando a la solución le contratar al pintor Isidoro Gurea para

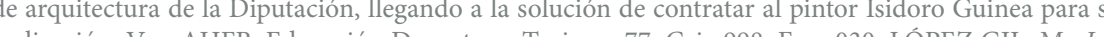
escudos de Carranza. Bilbao, Junta de Cultura Vasca, 1928

48 Boletín Oficial del Estado, n. ${ }^{\circ} 77,30$ de marzo de 1963, p. 5.363.

49 YBARRA Y BERGÉ, J.: Escudos de Vizcaya. Bilbao, Biblioteca Vascongada Villar, 1967, t. I, pp. 11-14

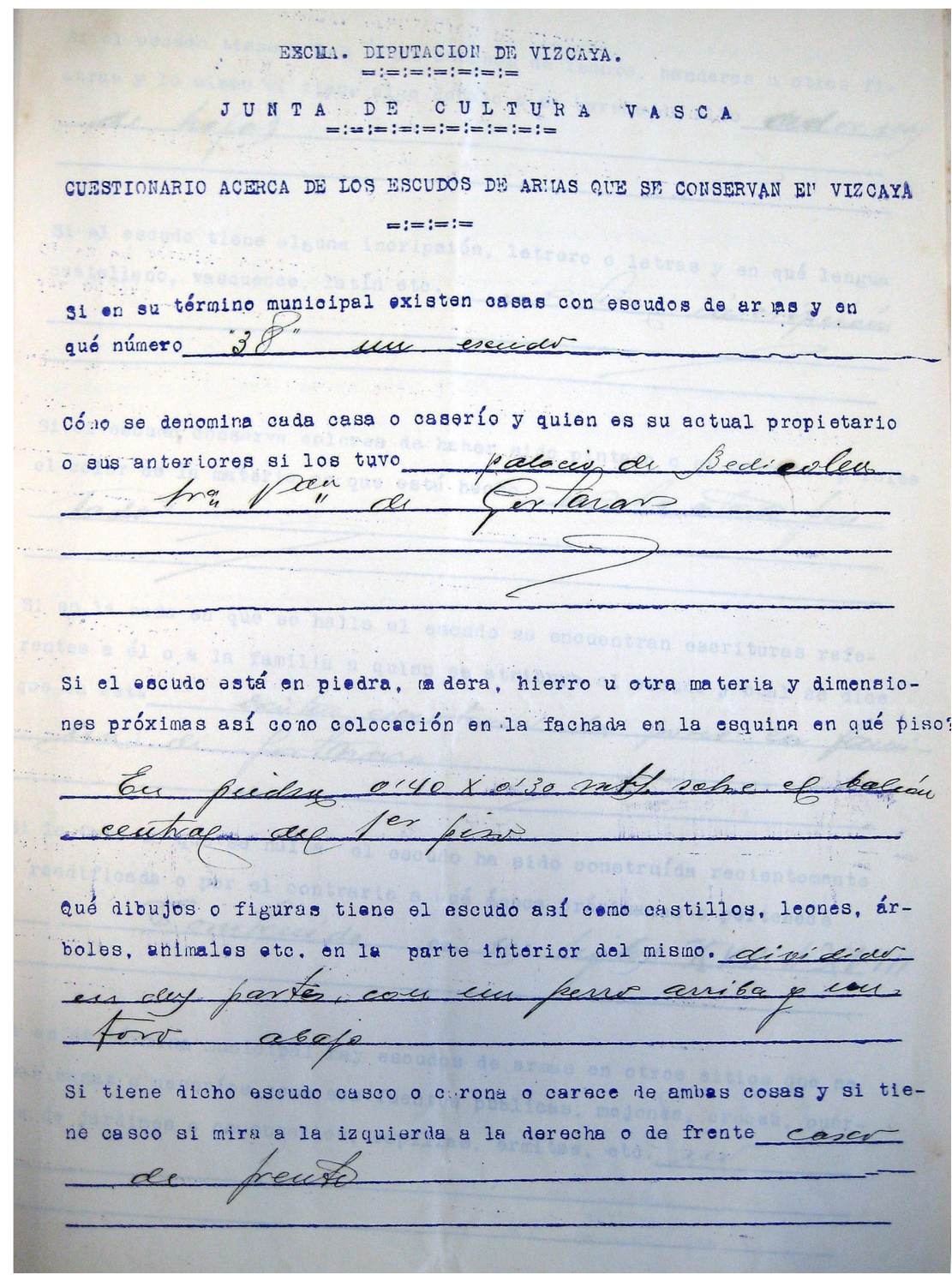

Fig. 3: Cuestionario de los escudos de armas de Vizcaya remitido por el Ayuntamiento de Ea (1921) AHFB. AGV - DC 1838/004. 


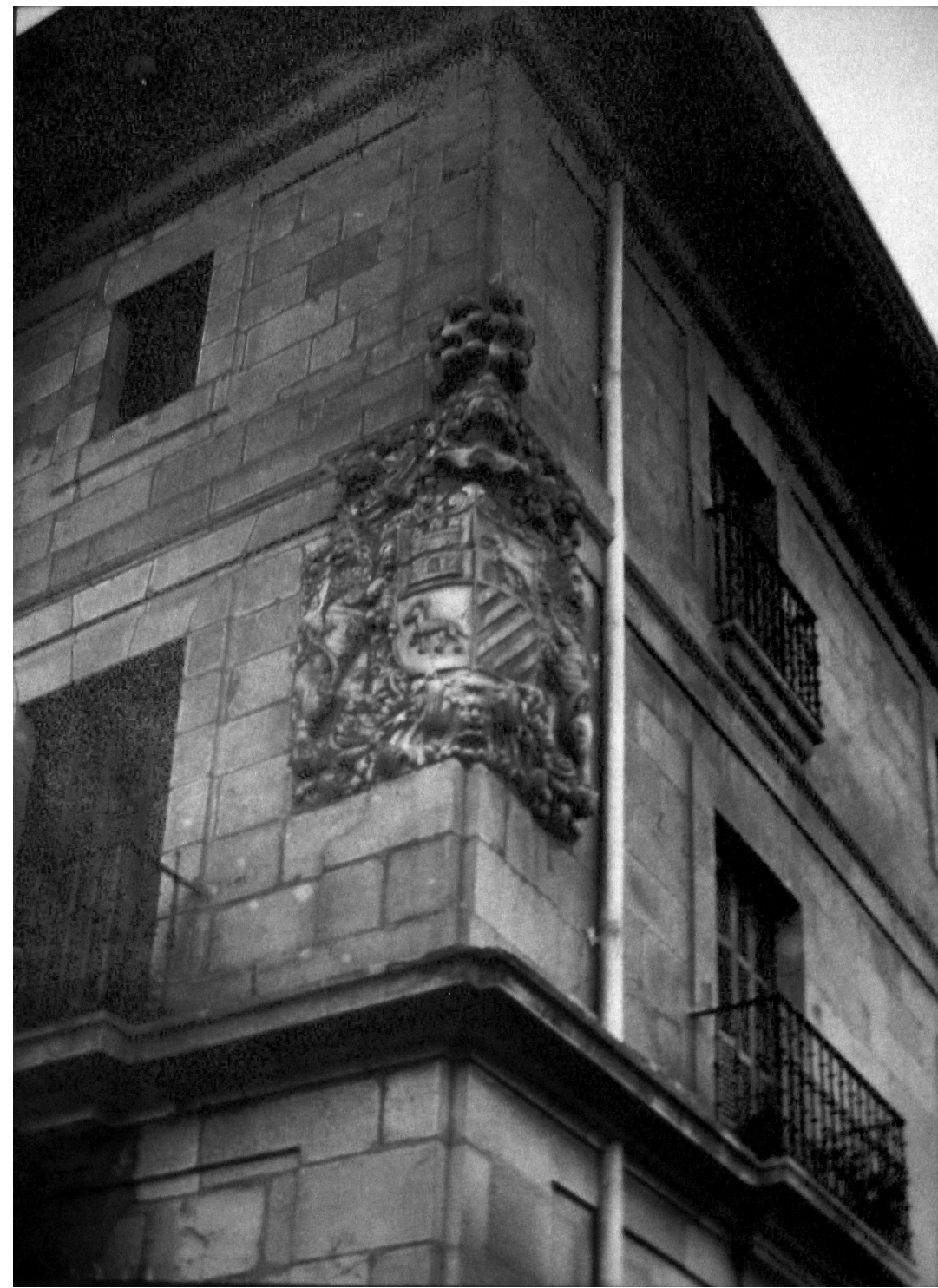

Fig. 4: Fotografía de los escudos de armas de Vizcaya remitido por el Ayuntamiento de Ea (1921), AHFB. AGV - DC 1838/004.
Javier Ybarra, precisamente, sería finalmente el autor del Catálogo de Monumentos de Vizcaya (1958), resultado de los estudios y recorridos histórico-artísticos iniciados junto a Pedro Garmendia en 1944, que fue publicado en plena dictadura franquista y con la JCV ahora denominada Junta de Cultura de Vizcaya. Previo a ello, las oportunidades que la JCV tuvo para emprender dicho proyecto fueron a nuestro juicio numerosas, siendo el conocido fotógrafo Manuel Torcida Torre, propietario de la Casa Lux de Bilbao, quien presentó las propuestas más factibles.

Apasionado excursionista y amante de los paisajes y rincones de la provincia, Torcida Torre acometía en 1918 su nuevo proyecto Vizcaya a principio del siglo XX. Su deseo era publicar una enciclopedia gráfica del Señorío compuesta por 24 volúmenes, cada uno dedicado a una región: "En ellos se estudiará cada zona, literaria y gráficamente, bajo sus distintos aspectos: geográfico, histórico, arquitectónico, industrial, mercantil, artístico, etc., etc.", reproduciendo desde retratos de hijos ilustres hasta objetos de interés histórico o artístico. Este apartado gráfico, compuesto por su colección de fotografías, se acompañaría de un texto descriptivo a cargo de Carmelo de Echegaray, mientras que la edición corresponderí a la casa viuda de L. Tasso de Barcelona; ambos garantizaban el éxito de la parte literaria y artística de la obra.

Para que esta "montaña gráfica" fuese lo más completa posible, Torcida Torre solicitó la colaboración de sus convecinos, optando de nuevo por el modelo del cuestionario para que le remitiesen datos y motivos. Las papeletas, divididas en ocho puntos, se interesaban por la geografía, historia, industria y comercio, agricultura y ganadería, turismo y, sobre todo, por el patrimonio arquitectónico de los pueblos: casas solariegas, torres o castillos "que aún existen" se incorporaban al epígrafe de historia; al punto de arquitectura correspondían las construcciones públicas y particulares notables, antiguas o modernas, iglesias, ermitas, cruces y "caseríos típicos, construcciones netamente vizcaínas"; el apartado de turismo hacía referencia a los paisajes y objetos artísticos; y en curiosidades tenían cabida todos aquellos edificios, lugares u objetos no incluidos en las secciones anteriores ${ }^{50}$.

50 AHFB. Sección Administrativo. Fondo Artes, Subvenciones y Becas Caja 2, Exp. 17. Anuncio de M nuel Torcida Torre, enero de 1918 


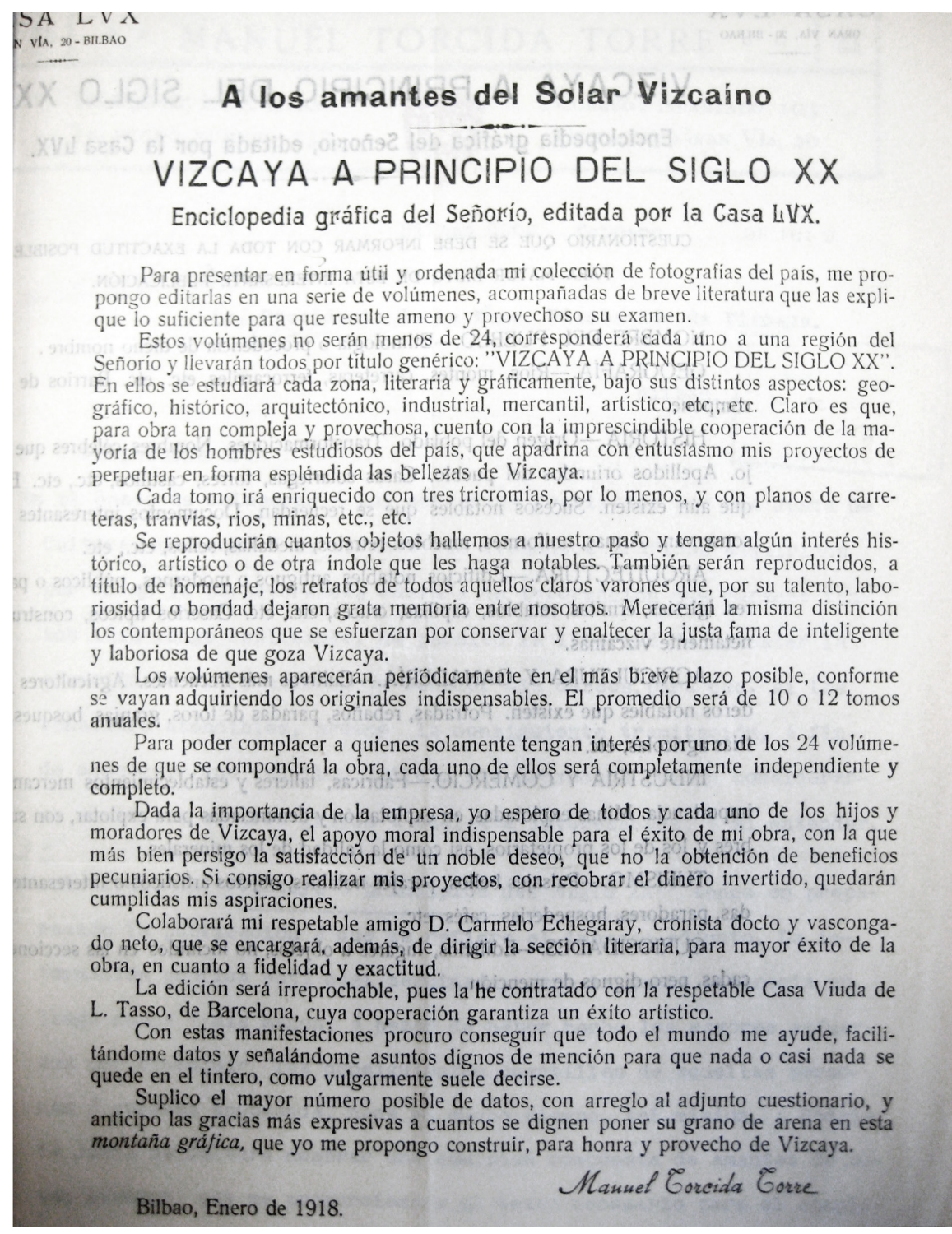

Fig. 5: Anuncio del proyecto "Enciclopedia gráfica del Señorío", Casa Lux (1918), AHFB. Sección Administrativo. Fondo Artes, Subvenciones y Becas Caja 2, Exp. 17.
Pasado el tiempo, el apartado gráfico estaba concluido, sin embargo la parte literaria encargada a Carmelo de Echegaray, "no llega nunca a mis manos, a pesar de haber hecho los mayores esfuerzos por conseguir las consiguientes cuartillas". El fotógrafo, en vista de esta situación, decidió implicar a la JCV en el proyecto: "¿Podría la Junta de Cultura nombrar una comisión compuesta de amantes de estas labores, que me proporcionara el texto necesario para el completo del original de mi obra?"; ofreció, además, su archivo gráfico para que fuera supervisado por "personas técnicas" y así definir nuevos asuntos de interés. El fotógrafo, de manera rápida y económica, ponía su colección en manos de la JCV para completar los estudios que ésta venía realizando; él, por su parte, solicitaba su nombramiento como cronista gráfico de la región, cargo sin retribución que le facilitaría la colaboración para sus proyectos ${ }^{51}$.

La JCV decidió cooperar en parte en la empresa. Aunque no nombró ninguna comisión para la redacción de Vizcaya a principio del siglo XX, se comprometió a "invitar oficialmente" a las personas comprometidas con el fotógrafo a concluir la obra (no olvidemos que Carmelo de Echegaray formaba parte de la JCV). Por otra parte, acordó que la comisión de artes plásticas y el arquitecto provincial orientasen a Torcida Torre en la elección de temas interesantes de la región y así completar su archivo. También optaron por darle toda clase de facilidades para emprender sus trabajos, pero no se le nombró cronista gráfico de Bizkaia $^{52}$.

La obra nunca llegó a publicarse, y no por falta de voluntad y entusiasmo del fotógrafo, que en 1919 comunicaba a la JCV la conclusión del primer cuaderno dedicado al Duranguesado. Seguían las dificultades para completar la parte literaria del resto de la obra, de ahí que insistiese a la JCV para que nombrase a una persona responsable de la tarea. Él, por su parte, reiteraba su compromiso de colaborar con el organismo, formando álbumes o carpetas fotográficas "de todos aquellos objetos o asuntos que pudieran tener interés para sus estudios", en condiciones ventajosas: "Yo mismo me encargaría de ordenar y rotular convenientemente las fotografías encargadas, formando así un magnífico catálogo gráfico, [...], los gastos de viaje serían de mi cuenta, pues aprovecharía las ocasiones que me proporcionan mis frecuentes excursiones" 53

51 El escrito aludía además a la publicación de una geografía del país, "en forma de vistas de proyección" para difundir entre los jóvenes, gráficamente y acompañada de un texto pedagógico, lo bello y lo útil que existía en la provincia. El mismo Torcida Torre se ofrecía a visitar las escuelas y alquilar a un precio económico los aparatos de proyección y las conferencias geográficas que le pidieran.

52 Informe de la comisión de artes plásticas del 25 de febrero de 1919 y aprobado por la JCV el 26 de febrero de 1919 .

53 Escrito de Manuel Torcida Torre fechado el 17 de marzo de 1919. 
La publicación del primer tomo de Vizcaya a principio del siglo XX se anunció para julio de 1919. A la región del Duranguesado le seguirían las de Arratia, Somorrostro y Gernika; un total de 24 volúmenes con más de 200 fotografías cada uno. La obra daría visibilidad a tantos años de trabajo y tan importante número de paisajes, vistas, monumentos y tipos capturados por la cámara de Torcida Torre, quien anhelaba difundir, entre los vizcaínos y los foráneos, la desconocida y poco apreciada riqueza paisajística y arquitectónica de la provincia, "porque no se divulgaron suficientemente las bellezas que tan calladamente encierra". Vizcaya a principio del siglo XX sería el más completo estudio de la geografía, historia, arquitectura, industria, comercio y turismo de la provincia: "Con verdadero entusiasmo emprendimos hace ya muchos años la difícil empresa de inventariar gráficamente tantísimos asuntos interesantes como nos brinda este rico y complejo territorio vizcaíno. Con perseverancia excepcional recorrimos alturas, valles y poblados, consiguiendo organizar un interesante archivo fotográfico de más de 10.000 negativos, a cual más interesantes, obtenidos en nuestras múltiples excursiones. ¡Lástima grande sería que este trabajo extraordinario no llegara a producir sus beneficios máximos, divulgándole por medio de una edición adecuada a su importancia! Esto es, precisamente, lo que ahora nos proponemos realizar".

El proyecto frustrado de Torcida Torre tenía sus antecedentes directos en De Vasconia Colección de fotografías vascas editada por la Casa Lux (1912-1914), dirigido por él mismo, en Álbum gráfico descriptivo del país vascongado (1914-1915), dedicado a la provincia de Gipuzkoa y editado por Rafael Picavea, y en los numerosos portfolios editados por toda España. El primero era una colección de 11 carpetas formadas por una fotografía y un texto descriptivo-literario, correspondiendo a Torcida Torre el apartado gráfico y a las firmas de Pedro Guimón, Fernando de la Quadra Salcedo, Francisco de Iturribarria, Félix López del Vallado y el propio fotógrafo, el literario ${ }^{54}$. Un conjunto que pretendía manifestar, a

54 Las carpetas se publicaron en el siguiente orden: capeta n. ${ }^{\circ}$, "La M.N. anteiglesia de Mundaca" Manuel Torcida Torre; carpeta n. 2 "El Castillo de Butrón, de quien es señor el marqués de la Torrecilla" Sabino de Ayala (Fernando de la Quadra Salcedo); carpeta n. ${ }^{\circ} 3$, "Cristianas" Francisco de Iturribarria carpeta n. ${ }^{\circ}$, "Caserío vasco ¿Por qué es bello" Pedro Guimón; carpeta n. ${ }^{\circ} 5$ "Semblanza de Don Alonso de Ercilla y Zuñiga" Alfonso Martínez de Ercilla carpeta n.0 6 "Otoñal" José Marí de Terán; Aarpeta

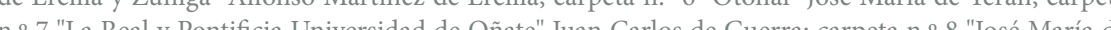

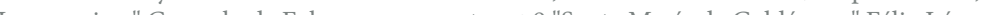
Iparraguirre" Carmelo de Echegaray; carpeta n. 9 "Santa Maria de Galdácano Felix Lopez del Vallado carpeta n. 10 "Puente de la muça" Santiago de Loizaga; carpeta n. ${ }^{\circ} 11$ "La casa solar de Traña-Jáuregui" Luis María de Uriarte Lebario. pequeña escala, los pueblos, costumbres y religiosidad, vida rural, caseríos, hijos ilustres, monumentos civiles y religiosos de Vasconia, aunque lo cierto es que casi la totalidad de las imágenes correspondieron a Bizkaia.

La obra editada por Rafael Picavea, por su parte, pretendía ser una descripción gráfica de todos los pueblos de Gipuzkoa acompañada de "datos histórico-geográficos" y de un conjunto de textos sobre los más diversos aspectos de la provincia (costumbres, bellas artes, industria, enseñanza, periodismo, casas solares, etc.), realizados por importantes firmas de la cultura vasca: Pio Baroja, Domingo de Aguirre, José María Salaverría, Francisco Grandmontagne, Pedro Mourlane Michelena, José María Donosty, Gregorio de Múgica o Carmelo de Echegaray. Una obra donde lo gráfico se imponía a los literario pues, como afirmaba Picavea: "El fotograbado se ha hecho tan necesario como la letra de molde"55.

Los portfolios eran un conjunto de imágenes fotográficas agrupadas en cuadernos que formaban un tomo o volumen encuadernable. De tamaño medio o de gran formato se editaban a bajo precio con fines culturales, científicos o divulgativos en respuesta a la cada vez mayor demanda de coleccionistas ${ }^{56}$. A comienzos del siglo XX comenzó a editarse en la casa A. Martín de Barcelona Portfolio fotográfico de España, dedicado a las diferentes provincias y capitales, correspondiendo su número 38 a Bizkaia ${ }^{57}$. Asimismo, fueron habituales los álbumes comerciales e industriales, de los que Bilbao ya contaba con algunos, como Sevilla artística e industrial (1911), Barcelona Artística e Industrial (1911) o Alicante y su provincia Artístico e Industrial (1918). Sánchez Vigil señala como uno de los portfolios fotográficos más interesantes de este período Portfolio de Galicia (1904) de Pedro Ferrer, donde las imágenes de monumentos, tipos y vistas se acompañaban de textos elaborados por autores reconocidos ${ }^{58}$. Una idea muy similar a las experiencias del País Vasco.

No hay duda de que el Vizcaya a principio del siglo XX, con sus 24 tomos, pretendía ser la obra más ambiciosa de cuantas se habían emprendido. La propuesta ofrecía, a nuestro juicio, la base necesaria para que la JCV iniciase la formación del catálogo del patrimonio

55 PICAVEA, R.: "Palabra preliminares". Álbum gráfico-descriptivo del País Vascongado. Años de 1914 1915, Rafael Picavea, 1915

56 ÁNCHEZ VIGIL, J. M.: "De la Restauración a la Guerra Civil", La fotografía en España. De los orígenes al siglo XXI. Madrid, Espasa-Calpe, 2002, p. 344 (Summa Artis, Historia General del Arte, t. XLVII).

57 Portfolio fotográfico de España. Provincia de Vizcaya. Barcelona, A. Martín, c. 1920.

58 SÁNCHEZ VIGIL, J. M.: op. cit., pp. 344-346. 
arquitectónico de Bizkaia. Sin embargo, en estos años aún no se había creado la sección de conservación de monumentos, recayendo en su comisión de artes plásticas estos asuntos; su existencia, no obstante, en nada hubiese cambiado el resultado. La sección de conservación de monumentos trató por primera vez la redacción de un catálogo, una de sus obligaciones, en 1921, interesándose por el procedimiento que se debía seguir en la "catalogación y conservación de monumentos"59. Paralelamente a las iniciativas para inventariar las ermitas y los escudos de armas, se propuso la publicación de un folleto sobre monumentos de Bizkaia, encomendado a Juan Carlos Gortazar, Pedro de Aguado y Carmelo de Echegaray ${ }^{60}$.

Un año después, Manuel Ramírez Escudero, ante las continuas destrucciones y reformas al que era sometido el patrimonio histórico-artístico, recordaba a la JCV la conveniencia de fijar gráficamente "cuanto de más interesante y valioso tengamos en los órdenes artístico y arqueológico por medio de la fotografía artística ampliada". La formación de un catálogo gráfico recuperaba en cierta medida la propuesta de Torcida Torre de crear una enciclopedia gráfica del Señorío; no en vano, Ramírez Escudero proponía solicitar a las casas fotográficas de Bilbao presupuesto para la reproducción de los motivos que la JCV acordase: "Estas reproducciones, bien enmarcadas, podrían ir a exornar los muros de nuestros museos Arqueológico o Etnográfico, según su índole, para cuya mejor y más rápida comprensión, pudiera colocarse al pie de cada cuadro una reseña concisa y clara, explicativa del mismo"61

Este catálogo gráfico se trataba de una suerte de "museo gráfico" donde reflejar las construcciones y objetos histórico-artísticos más destacados de Bizkaia, con destino a los museos Arqueológico y Etnográfico. La idea fue aprobada, se nombró una comisión y se decidió dividir el proyecto en dos partes, religiosa y civil, incluyendo además fotografías de caseríos y paisajes interesantes ${ }^{62}$. Se solicitó presupuesto a las casas fotográficas Amado, Espiga y Lux, y se encargó a Darío de Areitio la redacción de un "fichero bibliográfico" de

59 Acordado en sesión de 11 de febrero de 1921, en aquel momento se aprobó el cuestionario para el inventario de ermitas de la provincia.

60 Se designó a Carmelo de Echegaray, Juan Carlos Gortázar y Pedro de Aguado para emprender la tarea Acordado en sesión de 6 de abril de 1922.

61 AHFB. Sección Administrativo. Fondo Educación, Deportes y Turismo 67, Caja 988, Exp. 1. Moción de Manuel Ramírez Escudero presentada el 15 de enero de 1923.

62 Acuerdo del 3 de febrero de 1923, se designo a los vocales Antonio de Araluce, Juan Carlos Gortazar Pedro Aguado y Crescencio de Gardezabal para llevar a cabo la moción. las fotografías, "con lo que se poseerá un catálogo completo de los monumentos y demás obras artísticas de Vizcaya"63. La novedosa idea del fichero hubiese supuesto una de las iniciativas más interesantes de la JCV para la catalogación del patrimonio.

Así las cosas, Manuel Torcida Torre presentó la oferta más ventajosa: "debo advertir a Vd. que, desde mayo del año pasado, existe el acuerdo de la Junta de Cultura Vasca, de forma un Museo Gráfico de Vizcaya, a base de mis fotografías, y que dicho acuerdo no se lleva a la práctica, con perjuicio manifiesto para la Diputación y para mí, porque los señores encargados de proporcionarme las listas de asuntos interesantes, no tienen nunca tiempo de ocuparse del asunto y, de continuar las cosas así, dicho Museo Gráfico, no llegará a formarse jamás"64. El fotógrafo, ante la inactividad de la JCV, propuso remitir él mismo las fotografías y que aquella le devolviese las que considerara oportunas; un año después el organismo respondía a la misiva invitando a Torcida Torre a emprender los trabajos, supervisados por la comisión, y "dar cumplimiento al acuerdo de obtener fotografías de cuanto en Vizcaya existe en los órdenes artístico y arqueológico y de los caseríos y paisajes interesantes"6.

Nada más se supo del catálogo monumental, del fichero bibliográfico o del museo gráfico de la provincia, una tarea que tan fácilmente podía haberse impulsado gracias al trabajo de un artista que desde hacía décadas había aprehendido con su cámara lo que él consideró bello y característico de la provincia. Torcida Torre nunca perdió la esperanza de ver su proyecto publicado, y es que cuando se disponía a iniciar la obra Estampas de la tierruca, una historia gráfica de la Montaña que tampoco vería la luz, dirigía las siguientes palabras a la JCV: "¿Quién sabe si el éxito en el comienzo de mi empresa, me anima a lanzar otra publicación semejante, que se titule VIZCAYA PINTORESCA, en la que aparezcan tantas cosas interesantes como hay en Vizcaya, casi todas ellas existentes ya en mi archivo!"66. La obra más parecida al deseo de Torcida Torre se publicó tras su muerte. Lo admirable de Vizcaya (1934), "un portafolio completo de todas las bellezas naturales de la región,

63 Acordado el 21 de febrero de 1923

64 Escrito de Manuel Torcida Torre dirigido al presidente de la Diputación, fechado el 3 de enero de 1924. 65 Acordado en sesión de 28 de febrero de 1925

66 AHFB. Sección Administrativo. Fondo Educación, Deportes y Turismo 60, Caja 981, Exp. 7. Misiva fechada el 19 de agosto de 1927. 
de sus costumbres típicas y de las riquezas arquitectónicas que atesora nuestro pueblo"67 fue financiada en parte por la JCV y editada por Luis Santos, quien anteriormente había publicado Lo admirable de Guipúzcoa (1932). La obra se componía de un conjunto de fotografías, suyas y de su hijo Luis Torcida, y de textos de asuntos diversos firmados por Darío de Areitio, Miguel de Unamuno, Pedro Mourlane Michelena, Juan de la Encina, Fernando de la Quadra Salcedo, Ramón de Basterra o Engracio Aranzadi.

La figura de Manuel Torcida Torre, su intento de formación de una enciclopedia gráfica y la idea del "museo gráfico" presentado por Ramírez Escudero, remiten a las experiencias promovidas por Jeroni Martorell, como L'inventari grafic de Catalunya (1909) y la formación del Arxiu Mas. Cataluña iniciaba entre los años 1907 y 1909 una serie de proyectos donde el patrimonio histórico y la fotografía estaban íntimamente unidos. El Institut d'Estudis Catalans organizó en 1907 una Campanya Arqueologica pel Pirineu, entre cuyos integrantes destacaban el arquitecto Josep Puig i Cadafach y el fotógrafo Adolf Mas. Esta experiencia tuvo como resultado una colección de más de 250 fotografías y despertó el interés por el estudio, restauración y conservación del arte románico catalán ${ }^{68}$. Jeroni Martorell, por su parte, pronunció una conferencia en el Centre Excursionista de Catalunya proponiendo la formación de un inventario gráfico de Cataluña ${ }^{69}$ : "Les nacions civilisades s'en preocupen de la formació d'inventaris fràfics de les obres d'art, que procuren desenrotllar ab esplendidesa. Catàlecs, arxius de clixés y fotografies, museus de reproduccions, museums nacionals, són el medi de que's valen els pobles cultes pera inventariar les seves riqueses artistiques y fer ne l'historia"70.

Ante la incapacidad del Estado para proponer un modelo y metodología válido para formar el catálogo monumental de la nación, Martorell volvía la mirada hacia Francia y su Comisión de Monumentos Históricos, encargada de reunir una colección fotográfica sobre la riqueza artística de la nación, monumentos, pinturas murales, vidrieras, textiles, etc., con

67 AHFB. Sección Administrativo. Fondo Cultura Caja 1218, Exp. 14. El 30 de mayo de 1934 Luis Santo solicitaba el auxilio económico de la Diputación por medio de la adquisición de ejemplares, así en sesión de 20 de junio de 1934, la JCV acordó comprar 50 ejemplares a 40 pesetas cada uno.

68 En 1909 Josep Puig i Cadafalch, Antoni de Falguera y José Goday i Cassals comenzarían la publicación de "L'Arquitectura romànica a Catalunya". Ver: L'Arquitectura romànica a Catalunya. Barcelon

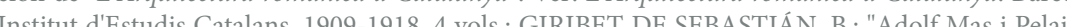
(f)

Cotografs dart a

69 Conferencia impartida el 31 de diciembre de 1908. Ver: MARTORELL, J.: L'Inventari grafic de Catalunya. Barcelona, Tipografía L'Avenç, 1909.

70 Ibid., p. 9 un catálogo editado de más de 11.000 fotografías. Así, el Institut d'Estudis Catalans encargó en 1909 a Adolf Mas la formación del inventario iconográfico, futura base del Arxiu Mas ${ }^{71}$. "El Archivo Mas fue fundado hace unos años por el gran artista fotógrafo don Adolfo Mas, alma de la institución, a indicaciones de los arquitectos notables, don Luis Doménech y Muntaner y don José Puig y Cadafalch, y en un principio tenía por único objeto el obtener el inventario gráfico de Cataluña. Durante esta primera fase de su actividad reunió en breve plazo unos veinticinco mil negativos de todo lo que constituía la riqueza de Cataluña, tanto en escultura como en pintura y monumentos, etc."72

Jeroni Martorell afirmaba que los primeros pasos para la formación del catálogo eran la consulta de publicaciones, la localización de colecciones fotográficas y el contacto directo con el patrimonio histórico-artístico ${ }^{73}$, ideas que la JCV tenía que conocer gracias a la conferencia pronunciada en 1921 por el arquitecto en Bilbao. La iniciativa de Torcida Torre no era la solución a la formación del catálogo, pero sí un punto de partida que debía proseguirse estableciendo objetivos, métodos de trabajo, visitas a las construcciones, elaboración de fichas (nada sabemos si Areitio redactó alguna), y contactando con otro organismos también interesados en estos asuntos, como la Sociedad de Estudios VascosEusko Ikaskuntza. La JCV nada hizo en este sentido, y los expedientes relativos a la formación de un catálogo monumental acabaron durmiendo un sueño eterno.

71 El Arxiu Mas, fundado en 1900, supone el modelo de archivo fotográfico del primer tercio del siglo XX Mas, además de captar la riqueza artística de Cataluña, emprendió una importante labor documenta por España, junto a su hijo Pelayo, viajando por Asturias, Castellón, Galicia y Navarra, entre otros puntos. Además recibió encargos de importantes instituciones americanas para emprender campañas por toda España: Hispanic Society of America, Institute of Fine Arts o Frick Arte Reference Library, entre otros. En 1941 la colección contenía 106.026 negativos, y con ellos se formó parte del Intitut Amatler d'A t Hispanc. GIRIBET DE SEBASTÍ́, B. op.cit. p. 100; SÁNCHEZ VIGIL J M: op. cit. Pp. d'Art Hispanic. GIRIBET DESEBASTIAN, B. Op cit., p . 344; BLANCH ALMUZARA, M.. El archivo Mas de fotografia , en Historia de la fotografía española 1839-1986. Sevilla, Sociedad de Historia de la fotografía española, 1986, pp. 393-394

72 "Archivo Mas", El progreso fotográfico. Revista mensual de fotografía y cinematografía, año VII, n. ${ }^{\circ} 67$ enero de 1926, p. 19 .

73 Leopoldo Torres Balbás apoyaba el método propuesto por Martorell, proponiendo también iniciar la redacción del inventario monumental tomando como base las publicaciones existentes y, una vez tomada la información, organizarlo siguiendo el modelo de fichas, que facilitaba la ampliación y corrección de

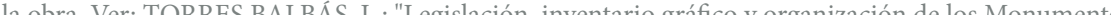

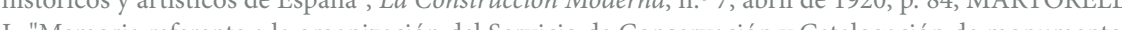
f.: "Memoria referente a la organización del Servicio de Conservación y Catalogación de monumentos que trata de establecer la excelentísima Diputación provincial de Barcelona", en Escritos de Jeroni Martorell i Terrats (hasta 1914). Barcelona, Diputación de Barcelona, 2001, p. 72. 
La catalogación en Bizkaia ha sido durante años, en palabras de José Ángel Barrio Loza, un "asunto de empeños personales de gente sensible al patrimonio monumental y al arte"74, pudiendo extenderse esta definición al resto del País Vasco y Navarra. A Javier Ybarra y su Catálogo de Monumentos de Vizcaya (1958) debe sumarse el primer tomo del Catálogo Monumental. Diócesis de Vitoria (1967) de Emilio Enciso Viana y Julián Cantera Orive, asumido posteriormente por la historiadora Micaela Portilla, y los estudios Navarre romane (1967) de Luis María de Lojendio y Arte medieval navarro (1971-1973) de José Esteban Uranga y Francisco Î́niguez ${ }^{75}$. A partir de la década de los ochenta se produjo un evidente interés por la redacción, no siempre publicados, de catálogos monumentales: Catálogo Monumental de la Diócesis de Bilbao (1986-1994) ${ }^{76}$, Inventario de Patrimonio HistóricoArtístico Inmueble de Gipuzkoa (1986-1988) ${ }^{77}$, Monumentos Nacionales de Euskadi (1985) y Catálogo Monumental de Navarra (1980-1997) ${ }^{79}$, continuándose la publicación del ya citado Catálogo Monumental. Diócesis de Vitoria (1967-2017) ${ }^{80}$.

El proyecto de elaboración de un catálogo monumental de España ha sido calificado de ambicioso, idealista o fracaso. Alfonso Muñoz Cosme expone cómo de los 47 trabajos de catalogación iniciados, sólo se concluyeron 31 y se publicaron $17^{81}$. Las causas de lo infructuoso del proyecto deben considerarse la ausencia de criterios específicos y de método de organización. En el caso de la JCV, a la falta de normativa, metodología y organización, se sumó la ausencia de especialización de sus individuos y un escaso compromiso con sus atribuciones. Hoy, como señala Muñoz Cosme, la documentación conservada de aquellos proyectos ha quedado como una "rareza documental"82. Sin embargo, supone un valioso testimonio del concepto de monumento y patrimonio de la época, un reflejo de la mplicación de la instituciones en la definición de políticas patrimoniales y un testimonio de la apreciación de parte de la sociedad hacia el patrimonio conservado. Y, por encima de todo, permite determinar los nombres propios que fueron generando un nueva sensibilidad artística de la que hoy somos deudores.

74 BARRIO LOZA, J. A.: "Inventarios y catálogos de Bizkaia", en Homenaje a Micaela Portilla: jornada congresuales. Vitoria-Gasteiz, Diputación Foral de Âlava, Departamento de Euskera, Cultura y Deportes, 2007, p. 18.

75 GÓMEZ GÓMEZ, A. "Catálogo monumental de Navarra", Revista Internacional de Estudios Vascos, n. ${ }^{4} 43,1998$, p. 189.

76 BARRIO LOZA, J. A.: Catálogo Monumental de la Diócesis de Bilbao, 1986-1994, inédito

77 ARETXAGA ALEGRÍA, S.: "El patrimonio arquitectónico alavés. Aproximación a su protección, catalogación y difusión", Ondare. Cuaderno de Artes Plásticas y Monumentales, n. ${ }^{\circ} 16,1997$, p. 116.

78 Monumentos Nacionales de Euskadi. Vitoria-Gasteiz, Departamento de Cultura, Gobierno Vasco, 1985.

79 Catálogo Monumental de Navarra. Pamplona, Gobierno de Navarra, Institución Príncipe de Viana Universidad de Navarra, 1980-1997, 9 vols.

80 Catálogo Monumental. Diócesis de Vitoria. Vitoria-Gasteiz, Obra Cultural de la Caja de Ahorros Municipal de Vitoria, Fundación Caja Vital Kutxa, 1967-2017, 11 vols

81 MUÑOZ COSME, A.: op. cit., p. 15.

82 MUÑOZ COSME, A.: op. cit., p. 36. 


\section{BIBLIOGRAFÍA}

"Archivo Mas", El progreso fotográfico. Revista mensual de fotografía y cinematografía, año VII, n. ${ }^{\circ} 67$, enero de 1926 , p. 19-24.

ARETXAGA ALEGRÍA, S.: "El patrimonio arquitectónico alavés. Aproximación a su protección, catalogación y difusión", Ondare. Cuaderno de Artes Plásticas y Monumentales, n. ${ }^{\circ} 16,1997$, pp. 107-142.

ARREGI AZPEITIA, G.: Ermitas de Bizkaia. Bilbao, Diputación Foral de Bizkaia, Instituto Labayru, 1987.

BARRIO LOZA, J. A. (dir.): Bizkaia. Arqueología, urbanismo y arquitectura histórica. Bilbao, Universidad de Deusto-Deiker, 1990.

BARRIO LOZA, J. A.: "Inventarios y catálogos de Bizkaia", en Homenaje a Micaela Portilla: jornadas congresuales. Vitoria-Gasteiz, Diputación Foral de Álava, Departamento de Euskera, Cultura y Deportes, 2007, pp. 15-20.

BARRIO LOZA, J. A.: Catálogo Monumental de la Diócesis de Bilbao, 1986-1994 (inédito).

BENAVIDES SOLÍS, J.: Diccionario razonado de bienes culturales. Sevilla, Editorial Padilla, 1999.

BLANCH ALMUZARA, M.: "El archivo Mas de fotografía", en Historia de la fotografía española 1839-1986. Sevilla, Sociedad de Historia de la fotografía española, 1986, pp. 393394.

Boletín del Instituto Heráldico. Ciencias histórico genealógicas, iconografía. Bilbao, Imprenta Erria, 1926.

Catálogo Monumental de Navarra. Pamplona, Gobierno de Navarra, Institución Príncipe de Viana, Universidad de Navarra, 1980-1997, 9 vols.

Catálogo Monumental. Diócesis de Vitoria. Vitoria-Gasteiz, Obra Cultural de la Caja de Ahorros Municipal de Vitoria, Fundación Caja Vital Kutxa, 1967-2017, 11 vols.

De Vasconia. Colección de fotografías vascas editada por la Casa Lux. Bilbao, Casa Lux, 1912-1914.
DÍEZ PATON, E.: Alma y piedra. Ideologías, conservación, restauración. Política del patrimonio arquitectónico en Vizcaya (1844-1936). Universidad del País Vasco, 2017 (tesis doctoral inédita).

GANAU CASAS, J.: La protección de los monumentos arquitectónicos en España y Cataluña, 1844-1936: legislación, organización, inventario. Lleida, Universidad de Lleida, 1999.

GARCÍA CUETOS, M.P.: El patrimonio cultural. Conceptos básicos. Zaragoza, Prensas Universitarias de Zaragoza, 2011.

GIRIBET DE SEBASTIÁN, B.: "Adolf Mas i Pelai Mas, fotògrafs d'art a Vilanova i La Geltrú", Butlletí de la Biblioteca Museu Balaguer, n. ${ }^{\circ}$ 5, 2012, pp. 97-111.

GÓMEZ GÓMEZ, A.: "Catálogo monumental de Navarra", Revista Internacional de Estudios Vascos, n. ${ }^{\circ}$ 43, 1998, p. 189-191.

GONZÁLEZ-VARAS, I.: Conservación de bienes culturales. Teoría, historia, principios y normas. Madrid, Cátedra, 2003.

L'Arquitectura romànica a Catalunya. Barcelona, Institut d'Estudis Catalans, 1909-1918.

LÓPEZ GIL, M.: Los escudos de Carranza. Bilbao, Junta de Cultura Vasca, 1928.

LOPEZ-YARTO ELIZALDE, A.: El catálogo monumental de España (1900-1961). Madrid, Consejo Superior de Investigaciones Científicas, 2010.

MARTORELL, J.: "El patrimonio artístico nacional", Arquitectura, año II, 1919, pp. 149161.

MARTORELL, J.: Escritos de Jeroni Martorell i Terrats (hasta 1914). Barcelona, Diputación de Barcelona, 2001.

MARTORELL, J.: L'Inventari grafic de Catalunya. Barcelona, Tipografía L'Avenç, 1909.

Monumentos españoles. Catálogo de los declarados nacionales, arquitectónico e históricoartísticos. Madrid, Blass, 1932.

Monumentos Nacionales de Euskadi. Vitoria-Gasteiz, Departamento de Cultura, Gobierno Vasco, 1985 
MUÑOZ COSME, A.: "Catálogos e inventarios del Patrimonio en España", en Catálogo monumental de España (1900-1961), investigación, restauración y difusión. Madrid, Ministerio de Educación Cultura y Deporte, Secretaría General Técnica, 2012, pp. 13-36.

ORDIERES DIEZ, I.: Historia de la restauración monumental en España (1835-1936). Madrid, Instituto de Conservación y Restauración de Bienes Culturales, 1995.

PICAVEA, R.: Álbum gráfico-descriptivo del País Vascongado. Años de 1914-1915, Rafael Picavea, 1915.

Portfolio fotográfico de España. Provincia de Vizcaya. Barcelona, A. Martín, c. 1920.

QUEROL, M.A.: Manual de gestión del patrimonio cultural. Madrid, Editorial Akal, 2010.

RISQUEZ CUENCA, C.: "Catalogación del patrimonio histórico. (Cuadernos. Instituto Andaluz del Patrimonio Histórico)", Arqueología y Territorio Medieval, vol. 4, 1997, pp. 243-246.

TORRES BALBÁS, L.: "Legislación, inventario gráfico y organización de los Monumentos históricos y artísticos de España", La Construcción Moderna, n. ${ }^{\circ}$ 7, abril de 1920, p. 83-84.

TUGORES, F. y PLANAS, R.: Introducción al patrimonio cultural. Gijón, Trea, 2006.

VV.AA.: La fotografía en España. de los orígenes al siglo XXI. Madrid, Espasa-Calpe, 2002 (Summa Artis, Historia General del Arte, t. XLVII).

YBARRA Y BERGÉ, J.: Catálogo de Monumentos de Vizcaya. Bilbao, Junta de Cultura de Vizcaya, 1958, 2 vols.

YBARRA Y BERGÉ, J.: Escudos de Vizcaya. Bilbao, Biblioteca Vascongada Villar, 1967. 